\author{
Oksana Makota and Lidiya Bulgakova
}

\title{
OXIDATION OF 1-OCTENE BY THE MOLECULAR OXYGEN IN THE PRESENCE OF IMMOBILIZED CATALYTIC COM POSITIONS
}

\author{
Lviv Polytechnic National University \\ 12, S. Bandera str., 79013 Lviv, Ukraine; makotaoksana@yahoo.com
}

Received: September 15, 2011 / Revised: December 01, 2011 / Accepted: M arch 15, 2012

(C) Makota O., Bulgakova L., 2012

\begin{abstract}
The influence of immobilized catalytic compositions, obtained by immobilization of cyanide complexes of transition metals: $\mathrm{Ni}, \mathrm{Pd}, \mathrm{Pt}, \mathrm{Co}, \mathrm{Fe}, \mathrm{Ru}$, and oxysalts of vanadium on the aluminum oxide as a carrier, on the initial stages of the liquid-phase oxidation reaction of 1-octene by the molecular oxygen was studied. It was established that the highest activity in the oxidation reaction of 1-octene by the molecular oxygen showed the catalytic composition containing immobilized ruthenium cyanide complex $\mathrm{K}_{2}\left[\mathrm{Ru}(\mathrm{CN})_{6}\right]-\mathrm{MnCl}_{2} \cdot 4 \mathrm{H}_{2} \mathrm{O} \quad$ (XI) whereas the activity of catalytic composition containing immobilized nicole cyanide complex $\mathrm{K}_{2}\left[\mathrm{Ni}(\mathrm{CN})_{4}\right]-$ $\mathrm{VO}\left(\mathrm{SO}_{4}\right) \cdot 3 \mathrm{H}_{2} \mathrm{O}(\mathrm{I})$ was the lowest one.
\end{abstract}

Keywords: oxidation, immobilized catalytic compositions, molecular oxygen, 1-octene, hydroperoxide.

\section{Introduction}

Various valuable oxygencontaining compounds are formed in the processes of liquid-phase oxidation of hydrocarbons by the molecular oxygen. They find a wide application in different branches of industry and as a result the investigation of the oxidation process is very important and actual [1-5]. The most perspective way of increase in the rate and selectivity of the oxidation reaction is application of various catalytic systems which influence definite stages of the oxidation process $[6,7]$.

Among catalytic systems of the liquid-phase oxidation of unsaturated compounds by the molecular oxygen a great attention attract immobilized catalytic compositions synthesized by chemical immobilization of transition metal complexes on carriers with a high surface. These catalytic systems combine high catalytic activity of a soluble metal complex system with a thermal and mechanical stability of heterogeneous systems [8-10].
Recently we have reported [11-13] about the results of the catalytic activity investigations of some homogeneous and immobilized complexes of rhodium, palladium, iridium and ruthenium in the liquid-phase oxidation reaction of 1-octene by the molecular oxygen. In the present work we present the results of studing the catalytic influence of other immobilized metal complexes on the initial stages of the liquid-phase oxidation reaction of 1-octene by the molecular oxygen.

\section{Experimental}

The commercial 1-octene (OC) of reagent pure grade was additionally distilled. The commercial solvent, chlorbenzene, chemically pure grade, was additionally dried and distilled. The molecular oxygen was purified prior to entering the reaction system; it was passed through $\mathrm{CaCl}_{2}$ and mixture $\mathrm{CaO}$ and $\mathrm{NaOH}$. tert-Butyl hydroperoxide (TBHP) was synthesized from tert-butyl alcohol and hydrogen peroxide in the presence of sulfuric acid by the procedure described in [14].

Immobilized catalytic compositions (Cat) (Table) were prepared by the procedure described in [13]. Aluminum oxide ( $\gamma$-form, Woelm) was dried at $373 \mathrm{~K}$, degassed and saturated with a dry argon. To modify the carrier by transition metal (M) cyanides water solutions of $\mathrm{NiSO}_{4} \cdot 7 \mathrm{H}_{2} \mathrm{O}, \quad \mathrm{K}_{2}\left[\mathrm{Pd}(\mathrm{CN})_{4}\right], \quad \mathrm{K}_{2}\left[\mathrm{Pt}(\mathrm{CN})_{4}\right], \quad \mathrm{CoCl}_{2} \cdot 3 \mathrm{H}_{2} \mathrm{O}$, $\mathrm{K}_{3}\left[\mathrm{Fe}(\mathrm{CN})_{6}\right], \quad \mathrm{VO}\left(\mathrm{SO}_{4}\right) \cdot 3 \mathrm{H}_{2} \mathrm{O}$ and $\mathrm{Ru}(\mathrm{OH}) \mathrm{Cl}_{3}$ in the amount of 1 mas \% of the compound to a weighed sample of $\mathrm{Al}_{2} \mathrm{O}_{3}$ were added to aluminum oxide. The resulting mixture was dried at $373 \mathrm{~K}$ to the loose state. To the obtained materials (except $\mathrm{VO}\left(\mathrm{SO}_{4}\right) \cdot 3 \mathrm{H}_{2} \mathrm{O}$ and samples already containing cyanide groups) a solution of $\mathrm{KOH}$ and acetone cyanohydrin in water were added. The mixture was stirred at $343 \mathrm{~K}$; the method is described in [15]. The products were filtered off, washed with water and dried at $373 \mathrm{~K}$ to the constant weight. 
To obtain the immobilized bimetallic catalytic compositions, to a weighed sample of carrier, modified by cyanide of metal $\mathrm{M}$, which is able to coordinate metal M', the solutions of the corresponding compounds in water in an amount corresponding to a molar ratio $\mathbf{M}^{\prime} / \mathrm{M}=1$ were added. In the case of compositions I, II, III, IV, VII, IX$\mathrm{VO}\left(\mathrm{SO}_{4}\right) \cdot 7 \mathrm{H}_{2} \mathrm{O}$ was used as compound of metal $\mathrm{M}^{\prime}$, for other compositions we used: $\mathbf{V}-\mathrm{Ru}(\mathrm{OH}) \mathrm{Cl}_{3}$, VI $\mathrm{RhCl}_{3} \cdot 4 \mathrm{H}_{2} \mathrm{O}, \mathbf{V I I I}-\mathrm{K}_{3}\left[\mathrm{Fe}(\mathrm{CN})_{6}\right], \mathbf{I X}-\mathrm{NiSO}_{4} \cdot 7 \mathrm{H}_{2} \mathrm{O}, \mathbf{X}-$ $\mathrm{MnCl}_{2} \cdot 4 \mathrm{H}_{2} \mathrm{O}$. After stirring for $1 \mathrm{~h}$, the solvent was removed by evaporation on a water bath. The product was dried at $373 \mathrm{~K}$ till the weight became constant.

The oxidation reaction of 1-octene by the molecular oxygen in the presence of immobilized catalytic compositions in the amount which corresponds to 0.36 mol of deposited metal complex was carried out in a glass reactor equipped with a magnetic stirrer and constant temperature jacket. The kinetics of the process was measured by the change of the the molecular oxygen volume at a gasometric unit [16] at $333 \mathrm{~K}$ and $90 \mathrm{kPa}$ of the oxygen pressure. The stirrer rotation rate $1000 \mathrm{rpm}$ is sufficient to ensure the reaction to proceed in the kinetic regime.

The rate of 1-octene oxidation process by the molecular oxygen $\left(W_{\mathrm{o}}\right)$ was determined from the oxygen absorption curve by the extrapolation of the obtained dependence to a zero time. It was established that the oxidation rate does not depend on the oxygen pressure when the pressure is higher than $50 \mathrm{kPa}$.

\section{Results and Discussion}

It was established by the preliminary experiments that purified and distilled 1-octene is not oxidized by the molecular oxygen in the presence of immobilized catalytic compositions under the reaction conditions for $2 \mathrm{~h}$.

It was shown that immobilized catalytic compositions influence the initial stages of the oxidation reaction of 1-octene by $\mathrm{O}_{2}$ only in the presence of homogeneous initiator, tert-butyl hydroperoxide.

The obtained results of the influence of immobilized catalytic compositions I-VI on the liquid-phase oxidation reaction of 1-octene by the molecular oxygen in the presence of TBHP in the reaction system are presented in Fig. 1.

One can see that all investigated immobilized catalytic compositions favour the oxidation reaction of 1 -octene in comparison with the noncatalytic process. The most intensive oxygen absorption in the oxidation process of 1-octene by the molecular oxygen is observed in the presence of immobilized compositions V. Other investigated immobilized catalytic compositions show a similar catalytic activity. The immobilized catalytic composition can be arranged in the following order of increasing their activated influence in the oxidation reaction of 1-octene by the molecular oxygen in the presence of TBHP in the reaction mixture: $\mathbf{I}<$ VI $<$ IV $<$ $<$ III $<$ II $<$ V.

Fig. 2 presents the kinetic curves for the oxygen absorption in the liquid-phase oxidation reaction of 1 -octene by the molecular oxygen in the presence of immobilized catalytic compositions VII-XI in the presence of tert-butyl hydroperoxide in the reaction system. It is seen that compositions VII-XI exhibit activated influence on the oxidation reaction of 1-octene as it was observed in the case of overmentioned compositions I-VI. However, the rate of the oxidation reaction in the presence of compositions VII-XI is significantly higher than for compositions I-VI.

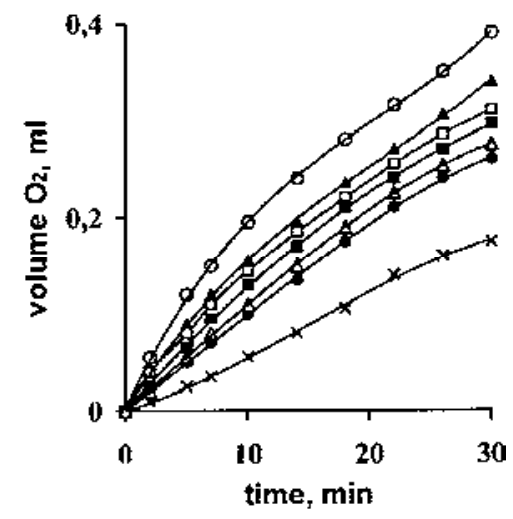

Fig. 1. The kinetic curves for the oxygen absorption in the liquid-phase oxidation reaction of 1-octene by the molecular oxygen in the presence of immobilized catalytic compositions:

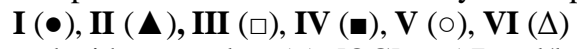
and without catalyst $(\times)$. $[\mathrm{OC}]_{\mathrm{o}}=5.7 \mathrm{~mol} / 1$, $[\mathrm{TBHP}]_{\mathrm{o}}=0.05 \mathrm{~mol} / \mathrm{l},[\mathrm{Cat}]=1 \mathrm{~g} / \mathrm{l}, T=333 \mathrm{~K}$

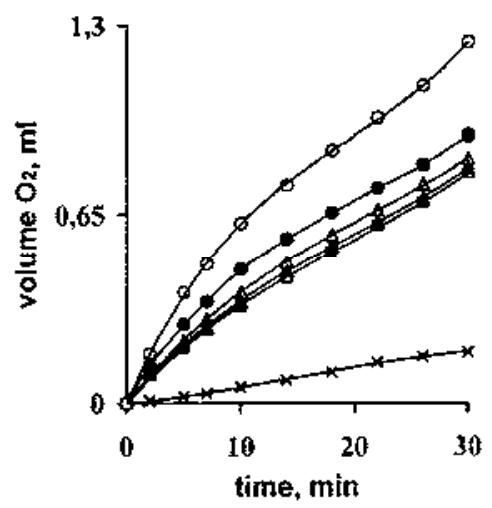

Fig. 2. The kinetic curves for the oxygen absorption in the liquid-phase oxidation reaction of 1-octene by the molecular oxygen in the presence of immobilized catalytic compositions: VII $(\Delta)$, VIII $(\square), \mathbf{I X}(\bullet), \mathbf{X}(\Delta), \mathbf{X I}(\circ)$ and without catalyst $(\times) .[\mathrm{OC}]_{\mathrm{o}}=5.7 \mathrm{~mol} / \mathrm{l},[\mathrm{TBHP}]_{\mathrm{o}}=0.05 \mathrm{~mol} / \mathrm{l},[\mathrm{Cat}]=1 \mathrm{~g} / \mathrm{l}$, $T=333 \mathrm{~K}$ 
Fig. 2 shows that the activity of immobilized compositions VIII and $\mathbf{X}$ is the lowest one and the curves of the oxygen absorption in the oxidation reaction of 1 -octene in their presence practically coincide. The composition VII and especially composition IX exhibit a little bit more activated influence on the oxidation reaction in comparison with compositions VIII and $\mathbf{X}$. The highest catalytic activity in the oxidation reaction of 1-octene by the molecular oxygen is observed in the case of composition XI and the highest value of the oxidation reaction rate is achieved in its presence (Table). The activity of investigated immobilized catalytic compositions in the oxidation reaction of 1-octene by the molecular oxygen in the presence of TBHP in the reaction system increases in the following order: VIII, $\mathbf{X}<$ VII $<$ $<$ IX $<$ XI.

Table

The rate of the oxidation of 1-octene by the molecular oxygen in the presence of immobilized catalytic compositions

\begin{tabular}{|l|c|}
\hline \multicolumn{1}{|c|}{ Immobilized catalytic composition } & $W_{\circ} \cdot 10^{6}, \mathrm{~mol} /(\mathrm{l} \cdot \mathrm{s})$ \\
\hline without catalyst & 1.13 \\
\hline $\mathrm{K}_{2}\left[\mathrm{Ni}(\mathrm{CN})_{4}\right]-\mathrm{VO}\left(\mathrm{SO}_{4}\right) \cdot 3 \mathrm{H}_{2} \mathrm{O}(\mathbf{I})$ & 3.16 \\
\hline $\mathrm{K}_{2}\left[\mathrm{Pd}(\mathrm{CN})_{4}\right]-\mathrm{VO}\left(\mathrm{SO}_{4}\right) \cdot 3 \mathrm{H}_{2} \mathrm{O}(\mathbf{I I})$ & 6.76 \\
\hline $\mathrm{K}_{2}\left[\mathrm{Pt}(\mathrm{CN})_{4}\right]-\mathrm{VO}\left(\mathrm{SO}_{4}\right) \cdot 3 \mathrm{H}_{2} \mathrm{O}(\mathbf{I I I})$ & 6.06 \\
\hline $\mathrm{K}_{3}\left[\mathrm{Co}(\mathrm{CN})_{6}\right]-\mathrm{VO}\left(\mathrm{SO}_{4}\right) \cdot 7 \mathrm{H}_{2} \mathrm{O}(\mathbf{I V})$ & 4.81 \\
\hline $\mathrm{K}_{3}\left[\mathrm{Co}(\mathrm{CN})_{6}\right]-\mathrm{RuOHCl}{ }_{3}(\mathbf{V})$ & 9.12 \\
\hline $\mathrm{K}_{3}\left[\mathrm{Co}(\mathrm{CN})_{6}\right]-\mathrm{RhCl}_{3} \cdot 4 \mathrm{H}_{2} \mathrm{O}(\mathbf{V I})$ & 3.66 \\
\hline $\mathrm{K}_{3}\left[\mathrm{Fe}(\mathrm{CN})_{6}\right]-\mathrm{VO}\left(\mathrm{SO}_{4}\right) \cdot 3 \mathrm{H}_{2} \mathrm{O}(\mathbf{V I I})$ & 16.48 \\
\hline $\left.\mathrm{VO}(\mathrm{SO})_{4}\right) \cdot 3 \mathrm{H}_{2} \mathrm{O}-\mathrm{K}_{3}\left[\mathrm{Fe}(\mathrm{CN})_{6}\right](\mathbf{V I I I})$ & 15.03 \\
\hline $\mathrm{K}_{2}\left[\mathrm{Ru}(\mathrm{CN})_{6}\right]-\mathrm{VO}\left(\mathrm{SO}_{4}\right) \cdot 3 \mathrm{H}_{2} \mathrm{O}(\mathbf{I X})$ & 21.24 \\
\hline $\mathrm{K}_{2}\left[\mathrm{Ru}(\mathrm{CN})_{6}\right]-\mathrm{Ni}_{2}\left(\mathrm{SO}_{4}\right) \cdot 7 \mathrm{H}_{2} \mathrm{O}(\mathbf{X})$ & 15.25 \\
\hline $\mathrm{K}_{2}\left[\mathrm{Ru}(\mathrm{CN})_{6}\right]-\mathrm{MnCl}_{2} \cdot 4 \mathrm{H}_{2} \mathrm{O}(\mathbf{X I})$ & 29.92 \\
\hline
\end{tabular}

The given results show that all investigated immobilized catalytic compositions exhibit the activated influence on the initial stages of the liquid-phase oxidation reaction of 1-octene by the molecular oxygen in the presence of tert-butyl hydroperoxide. However, their catalytic activity is different and depends on the nature of immobilized complexes. The highest catalytic activity shows the composition XI containing immobilized ruthenium cyanide complex. The activity of other compositions, $\mathbf{V}, \mathbf{I X}, \mathbf{X}$, containing immobilized ruthenium cyanide complexes as in [4], is also high in comparison with other catalytic compositions investigated in this work. It is interesting to note that the high value of the oxidation reaction rate is also observed in the presence of catalytic compositions VII and VIII which contain ferrum cyanide complexes. The lowest value of the oxidation reaction rate is obtained when composition $\mathbf{I}$ containing immobilized nicole cyanide complex is used as a catalyst. Immobilized compositions II-IV slightly differ in catalytic activity and the rate value of the oxidation reaction of 1-octene by the molecular oxygen in their presence is not high.

\section{Conclusions}

Thus, the obtained results show that all investigated immobilized catalytic compositions exhibit catalytic activity in the initial stages of the liquid-phase oxidation reaction of 1-octene by the molecular oxygen in the presence of tert-butyl hydroperoxide. Composition XI containing immobilized ruthenium cyanide complex is the most active whereas composition I containing immobilized nicole cyanide complex is less active in the oxidation reaction.

\section{Acknowledgements}

Authors are thankful to Varshavskii Yu.S. and his coworkers (St. Peterburg State University) for cooperation and preparation of immobilized catalytic compositions.

The work was supported by the Fundamental Researches State Found of Ukraine (grant F28/256-2009).

\section{References}

[1] Weissermel K. and Arpe H.-J.: Industrial Organic Chemistry, Wiley-VCH, Weinheim 2003.

[2] Adam W. (Ed): Peroxide Chemistry. Mechanistic and Preparative Aspects of Oxygen Transfer. Wiley-VCH, Weinheim 2000.

[3] Marco-Contelles J., Molina M.T. and Anjum S.: Chem. Rev., 2004, 104, 2857.

[4] Yudin A.: Aziridines and Epoxides in Organic Synthesis. WileyVCH, Weinheim 2006.

[5] Diez D., Beneitez M., Marcos I. et al.: Tetrahedron: Asymmetry, 2002, 13, 639.

[6] Jorgensen K.: Chem. Rev., 1989, 89, 431.

[7] Sheldon R.: J. Mol. Catal., 1980, 7, 107.

[8] Xia Q.-H., Ge H.-Q., Ye C.-P. et al.: Chem. Rev., 2005, 105, 1603.

[9] Hodnett B.: Heterogeneous Catalytic Oxidation. Fundamental and Technological Aspects of the Selective and Total Oxidation of Organic Compounds. John Wiley \& Sons, NY 2000.

[10] Arends I.W.C.E., Sheldon R.A.: Appl. Catal. A, 2001, 212, 175.

[11] Trach Yu., Makota O., Cherkasova T. et al:: Rus. J. Gen. Chem., 2010, 80, 1040.

[12] Trach Yu., Makota O., Bulgakova L. et al.: ibid, 1207.

[13] Bulgakova L., Makota O., Starchevskii V. et al.: Rus. J. Gen. Chem., 2011, 81, 869.

[14] Milas N. and Surgenor D.: J. Amer. Chem. Soc., 1946, 68, 205.

[15] Varshavskii Yu. and Cherkasova T.: Zh. Obshch. Khimii, 2010, 80, 332.

[16] Tsepalov V.: Zavod. Lab., 1964, 1, 111. 
ОКИСНЕННЯ ОКТЕНУ-1 МОЛЕКУЛЯРНИМ КИСНЕМ У ПРИСУТНОСТІ ІММОБІЛІЗОВАНИХ КАТАЛІТИЧНИХ КОМПОЗИЦЙ

Анотація. Вивчено вплив іммобілізованих каталітичних композичій, одержаних іммобілізачією ціанідних комплексів перехідних металів: $\mathrm{Ni}, \mathrm{Pd}, \mathrm{Pt}, \mathrm{Co}, \mathrm{Fe}, \mathrm{Ru}$, та оксосолей ванадію на оксид алюмінію як носій, на реакиію рідиннофазного окиснення октену-1 молекулярним киснем на початкових стадіях процесу. Встановлено, щуо найактивнішою в реакиії окиснення октену-1 молекулярним киснем $\epsilon$ каталітична композиція, до складу якої входить іммобілізований иіанідний комплекс рутенію $\mathrm{K}_{2}\left[\mathrm{Ru}(\mathrm{CN})_{6}\right]-\mathrm{MnCl}_{2} \cdot 4 \mathrm{H}_{2} \mathrm{O}$ (XI) тодi як активність композиції, яка містить іммобілізований ціанідний комплекс нікелю $\mathrm{K}_{2}\left[\mathrm{Ni}(\mathrm{CN})_{4}\right]-\mathrm{VO}\left(\mathrm{SO}_{4}\right) \cdot 3 \mathrm{H}_{2} \mathrm{O}(\mathrm{I})$ є найнижчою.

Ключові слова: окиснення, іммобілізована каталітична композиція, молекулярний кисень, октен-1, гідропероксид. 